\title{
Factors that Motivates the Teacher Trainees of Teacher Training Institutions to Possess an Excellent Personality through Hermeneutic Analysis Method
}

\author{
Suppiah Nachiappan ${ }^{1}$, Hari Krishnan Andi ${ }^{1}$, Sunder Subbramaniam ${ }^{1} \&$ Velayudhan P. K. Veeran ${ }^{1}$ \\ ${ }^{1}$ Faculty of Education \& Human Development, Sultan Idris Education University, Tanjung Malim, Malaysia \\ Correspondence: Suppiah Nachiappan, Faculty of Education \& Human Development, Sultan Idris University, \\ Tanjung Malim, 35900, Malaysia. Tel: 60-125-270-801. E-mail: suppiah@fppm.upsi.edu.my
}

Received: April 19, 2012

Accepted: May 7, $2012 \quad$ Online Published: August 2, 2012

doi:10.5539/jedp.v2n2p97

URL: http://dx.doi.org/10.5539/jedp.v2n2p97

\begin{abstract}
Motivation plays an important role in determining one's achievement level. Therefore, future teachers who are responsible in leading their pupils' need to be motivated so that they will be well prepared to face all the upcoming challenges in the education field. This research discusses on to what extent do the trainee teachers of Tamil option are familiar with the factors that motivate them to posses an excellent personality as a trainee teacher of Teacher Training Institute. The respondent's research has been analysed using the hermeneutic analysis. The finding of the research has shown that the trainee teachers of Tamil option are wise about the factors that motivate them to get hold of an excellent personality as a trainee teacher. About 14 motivational factors that motivate this trainee teacher's have been identified. These include the lecturers', learning facilities, encouragement from the family members, primary school teachers, classmates, ambitions, dreams or desires, teaching methods, teachers' role, teaching experience, the love for the mother tongue, self-confidence and life goals', surroundings, systematic concern and friendly administrations, co-curricular activities and outdoor education. This research has also identified the factors that trainee teachers know that it motivates them and the factors are useful. Thus, knowledge of knowing the motivating factors that the trainee teachers get hold of can be utilized by parties who are directly involved with the trainee teacher to plan and conduct more effective teaching and learning activity.
\end{abstract}

Keywords: hermeneutic analysis, trainee teachers, motivation, personality

\section{Introduction}

Education is a lifelong process, which reflects a society to be civilized. Education is not only a tool to impart knowledge but it is a channel used to educate an individual as well as to form individuals who are intellectually, spiritually, emotionally, and physically balanced. Therefore, educators need to equip themselves with good qualities that are required in order to uplift the education of our country to a higher level that can indirectly form more Malaysia citizens who are competent, skilful, knowledgeable and experienced. This will also protect the stability of our country and strengthen ones' life principles. Teachers need to be highly motivated and committed in carrying out their duty as a responsible educator.

\subsection{Importance of the Research}

There is no many research that has been done on the Indian ethnic's teenagers, especially the trainee teacher of Tamil Study. Actually many studies are essential to be conducted in order to facilitate the trainee teachers' who are undergoing the Tamil Study course for $51 / 2$ years in Teacher Training Institute all over Malaysia. The studies on these groups will help many parties to solve issues related to these Indian teenagers. This study will be helpful for all lecturers teaching the Tamil option in Teacher Training Institute all over Malaysia to face and solve issues related to these teacher trainees. Researcher too hopes that this study will serve as guidance for other individuals who will be undergoing this teaching course. On the other hand, this study can also serve as guidance for individual who are interested to become teacher. Lastly, researcher hopes that this study will be made as guidance by the Ministry of Education in solving issues related to trainee teachers who are undergoing Tamil option course.

Motivation and interest play important role in leading the students' in an institution to achieve certain goals that 
have been stated. The ability to apply the motivational theory in the teaching and learning context in an institution will improve one's productivity. The term motivation derived from a Latin word that means moving. Crow and Crow (1983) defined motivation as a moving force that influence one's satisfaction or dissatisfaction when undergoing certain situation which is closely related to the encouragement and interest that one owns or disown. Conversely, Hull (1943) has defined motivation as a variable set that sprain an individuals' attitude in leading and managing their attitude to strive for the achievement of their aims and work satisfaction.

\subsection{Research in Malaysia}

A research has been conducted among the trainee teachers of Teaching Course for Degree Holders (KPLI) and Diploma in Teaching (KDPM) in two Teacher Training Institutions in Johor. These trainee teachers' have been studied in the aspects of self-awareness, self-management, social awareness and social skills. Researcher found that the motivational element scores the highest score in self-management of trainee teachers' of KPLI. Researcher assumes that trainee teachers of KPLI are matured as they can plan, organize, perform, and involve themselves actively in certain projects. Other than that, they think openly and act positively as well as fulfill their promises. Their attitude is much aided by the encouragement of education as a teacher at the school later (Kamalularifin et al., 2005).

Sultan Abdul Halim, Sungai Petani Teacher Training Institute has conducted a study to identify the motivation in learning mathematics in the English language among the trainee teachers who are taking Mathematics as core subject (major) and trainee teachers who are taking Mathematics as elective subject (minor).

Trainee teachers who are taking Mathematics as core subject (major) show more positive attitude in learning Mathematics compared to trainee teachers who are taking Mathematics as a minor subject. Hence, the researcher suggested that trainee teachers who are taking Mathematics as a minor subject should be given more motivation in learning Mathematics. Lecturers who are teaching Mathematics should work hard to help the trainee teachers to build positive attitudes that can motivate the learning of Mathematics (Cheah et al., 2004).

Cheng (1996) in his study found that schools with strong cultures, the organization's environment that is rich in ideology, participation with, and charismatic leadership produce teachers who are motivated. In addition, collaborative culture also can enhance relations resulting in teachers experiencing high job satisfaction and increase in productivity.

\subsection{Abroad Researches}

Mulyasa (2005) in Muhammad et al., (2010) states among trainee teachers of Indonesian language at the University of New Syiah Kuala in Indonesia, are still many teachers who lack personal motivation to develop their profession as teachers. Researchers think generally the teachers in Indonesia are still less able to write scientific papers in the field of learning, using appropriate current technology for learning tool and create a work of art. Moreover, in Indonesia only a few teachers who continuously work hard with full self-awareness in order to develop their profession.

Several overseas studies found that the teaching profession influenced the selection of two types of motivation, intrinsic motivation and extrinsic motivation. One of the intrinsic motivations identified is interested in children (Ethington 1988; Bontempo \& Digman 1985; Evans 1993). Berry (1988) and Jantzen (1981) have also reported that the factors for being interested in children are a popular reason among the female candidates. Other reasons are as to serve the nation and the people (Chuen et al., 1999), a fun work environment (Brown 1992) and to take advantage of knowledge and opportunity to pursue their studies (Thomas 1984). On the contrary, for the extrinsic motivation factors such as job security, salary and future prospects and promotion opportunities are found in a study on the selection of the teaching profession among primary school teachers (Yong 1994; Chuen et al., 1999). However, Marshall (1986) adds that the influence of former teachers, the opportunity to enhance their social status, the notion that the inclusion in the teaching profession is easy and wants to share knowledge through teaching also contributed to the selection of the teaching profession.

\subsection{Application of Hermeneutics Analysis in Classroom}

Loganathan and Abdul Rahman have used the method of hermeneutics successfully in the study of classroom interaction between teacher and students during the teaching and learning process. Although this research is slightly different than Loganathan's study (1992) and Abdul Rahman study (1993), there are still many other important similarities. Similarities are their research and study using hermeneutics analysis and involve interaction between teachers and students. There are also several differences between these studies.

Many previous studies show that motivation among the trainee teachers' is influenced by a variety of situations either at college or during teaching practice, which is also known as practicum. As future teachers, trainee 
teachers' have variety of responsibilities and duties that have to be performed in line with the teaching profession requirement. The main and most important responsibility of a teacher is to stimulate, guide and develop students in the learning process. All efforts to that direction should be planned and implemented. Effective teachers in carrying out their duties are teachers who succeed in getting their students motivated in their studies. Thus, for effectiveness in teaching, trainee teachers should strive to understand the meaning of motivation to learn and develop the motivation as well as drive his/her motivation level to learn to the maximum level.

Currently, the social issue among the Indian ethnics especially teenagers in our country are frequently heard in the news. Nevertheless, we can see many Indians who have worked hard and excelled in the respective field that they are indulging in. To add, the trainee teachers in IPG are also teenagers who are pursuing their studies after their SPM examination. These people come from different family background. Hence, there must be some factors that had motivated them to become a teacher. However, the question that triggers in the mind of everyone is what are the types of motivation that the trainee teachers' should posses in order to be competent and knowledgeable teacher.

Hence, the objectives of the study are to identify the factors that motivate the achievement of the Tamil option trainee teachers in Teacher Training Institute and to determine to what extent do the Tamil option trainee teachers are aware of the factors that motivate their achievements in Teacher Training Institute.

\section{Research Methodology}

This study is in the form of hermeneutics analysis that used qualitative and interpretive approach. This study was conducted using case study design. Trainee teachers were asked to write essays based on provided questions within the time specified by the researcher. Respondents were told not to discuss among group members. Once the time allocated to write has finished, the answer scripts were collected to analyze. This study was conducted at the Institute of Teacher Education Campus Ipoh, Hulu Kinta in Perak. A total of 20 trainee teachers from the Bachelor of Teaching were selected as the sample for the study. All of them are trainees of January 2010 intake of Tamil Option Specialization. All the samples were selected among the Tamil Option Specialization trainee teachers' because previously there was no study done on the factors that motivate trainee teachers of Tamil Option Specialization in Teacher Training Institute.

\subsection{Research Instrument}

In this study, the instrument consists of trainee teacher information form and the essay that they have to write based on the given question. Trainee teacher information form was used to obtain information on teacher background such as gender, age, marital status, experience as a teacher and their ambitions before entering the IPG. Another instrument, i.e., the essay is the important aspect of this study. The essay written by sample study was used to analyse text using heremeneutic method. Hermeneutic derived from a Greek word, "hermeneuō", that means (Palmer, Richard E. 2003) Hermeneutic methods is one of the oldest method used by researches to analyze text (essay writing). It is used to interpret the gospels in the study of old Greek.

According to Suppiah (2003), in-depth analysis of the unconscious implicit elements in the text will enable researchers to achieve a meaningful understanding. This understanding is meta-texts that can give meaning to the text or students' writing. For example the text, the essay, short story or recording of the interview results of different meanings which cannot be understood through its first reading at its surface structure level. It should be interpreted at its deep structure to explicit the hidden meanings, thus reducing the ignorance in the texts.

\subsection{Features of Hermeneutic Method}

There are several features related to the analysis of hermeneutics, the text as material analyzes. Text is the production of human ability to demonstrate and analyze human behaviour and thinking. Dilthey (1976) states that hermeneutics science involves the art to read a text to know and understand the full hidden meaning with hidden desire. These characteristics are the existence of external structure and internal structure of the text simultaneously. All the text has two structures, the External Structure, and Internal Structure. External structure refers to explicit reference, which can be detected easily and directly from the text. When the text being studied is difficult to understand, the researchers had to seriously penetrate the hidden element into the Internal Structure. According to Loganathan (1996), "The Pointed" (Showing) and "The Seeing" (Seeing) are two important terms that describe in detail the meaning of something. When someone shows something to be learned, then the viewer will have the opportunity to learn something new. New understanding will occur and knowledge sharing will take place towards the strengthening, which will occur on an ongoing basis.

A text, as an example, an essay or records of interview results of different hidden meanings that cannot be understood by reading only once. In-depth analysis of the unconscious implicit elements in the text will enable 
researchers to achieve a meaningful understanding. This understanding is meta-texts that can give meaning to the text or one's writing.

\subsection{Elements of the Instrument, Validity and Reliability}

Elements which usually consist of a set of questionnaire, validity and reliability are very important in the hermeneutics scientific method. Certain data is used to establish the reliability and validity of the instrument. However, there was no instrument that involves any data in this study. Thus, the reliability and validity of the instrument in Hermeneutic need not to be discussed. Essay text is the main and important source of this study. Every text consists of at least two structures that are the external and internal structure. Usually text can be used to discuss about the reliability of a text and not the accuracy. A text is said to have credibility if it is created and recorded without any manipulation. The text must be produced in the spontaneous condition that the reliability of the text can be practiced.

\subsection{Research Procedures}

Before the questions were given to the samples, the researchers hold dialogue with all samples. Researchers and the samples have the opportunity to talk about the background of trainees and constraints faced while in the Teacher Training Institute and their experiences as trainee teachers during their time in this Teacher Training Institute. After the researcher explained the purpose of this study, this paper will be distributed to each sample. Each sample should answer the question in essay form. The allocated time to write the essay is only an hour. The samples of this study are not allowed to discuss each other when answering the questions.

\subsection{Data Analysis Procedures}

Once researchers have collected data from the sample, the researcher must find the meaning of the data, and this involves the process of data analysis. According to Strauss dan Corbin (1998), the process of data analysis is confusing, ambiguous, time consuming, creative and interesting. An ongoing process of review, re-define and categorising again in order to obtain accurate and meaningful analysis and interpretation.

\subsection{Data Collection and Processing}

The psychological impact is identified through reading in the process of interpreting text in the form of essay. Among the psychological effects that can be interpreted is the emotion for the last $31 / 2$ years ago as a trainee teacher, self-motivation of students towards their studies, the factors that motivate students to continue their studies for the upcoming 2 years, students' knowledge of their responsibilities as trainee teachers who are knowledgeable, dynamic changes that have been experienced over time in Teacher Training Institute as a student, next instilling the elements of teaching in themselves. Motivational elements are given the most priority by the researchers among all the other psychological effects mentioned.

\section{Research Findings}

For this study, respondents were asked to write essays to identify the factors that motivate excellence trainee teachers in the institute. Once collected, all essays were analyzed using hermeneutics method. An essay or text need to be analyzed in the aspects of external and internal structures through hermeneutic method. Here the external structure is the explicit contents while the internal structure is the implicit contents. Usually the explicit contents are easy to be comprehended but implicit contents are difficult to understand. Researchers need to read the respondents essay repeatedly to get the internal structure and external structure in order to understand the essay more in-depth.

In the essay that was written by the respondents in this study, the researchers were able to identify many factors that have influenced the respondents to motivate themselves to become an excellent teacher by reading the essay that was written by the respondents' in this study. Based on these facts identified, researchers were also able to identify factors that motivate the respondents to some pattern. These factors are identified solely by the respondents in which the respondents explained his/her real situation in the time spent in the Institute of Teacher Education Campus Ipoh.

\subsection{Respondents' Essay (Text)}

While reading, the researchers identified the motivational factors that have the capacity to urge the respondents' to become a successful trainee teacher and excel in the institute. After reading the text of the respondents, motivational factors have been bold and typed again at a nearby column.

\subsection{Motivational Factors}

After reading repeatedly, researchers found that the factors that motivate excellence in the Institute of Teacher 
Education Campus Ipoh trainees can be gathered in several patterns. These patterns are as follows:

\subsubsection{Lecturer}

This motivational factor was most mentioned by respondents. Lecturers who teach the trainee teachers were the main encouragers that motivate excellence in trainee teachers in this Teacher Training Institute. Of the 20 respondents, 15 respondents indicated that their lecturers' especially Tamil option lecturers inspired their motivation. They stated that their lecturers are their "role models" and the support given by the lecturer has motivated them. The advice given by the lecturer has motivated them to strive for excellence. Some trainee teachers consider the example shown by the lecturers as their motivating factor. While there were three respondents that stated guidance of lecturers is their motivation. Two respondents stated that learning styles indicated by the lecturer as the factor that motivated them. Trainee teachers also consider their lecturers are very dedicated in their work as a lecturer. Skills shown by the lecturer during the teaching and learning process also motivate them. Lecturer of ethical attitudes, such as being punctual to class too, motivates them. Two respondents consider the guidance given by their lecturer is very motivating. There were also some trainee teachers who feel that the commitment and intelligence of their lecturers' in handling the teaching and learning activities as a factor that motivate them to excel themselves. In addition, some trainee teachers claimed that they feel motivated due to their lecturers' personality and knowledge sharing attitude.

\subsubsection{Infrastructure Facilities}

A total of 9 respondents stated that the facilities available in the Institute of Teacher Education Campus Ipoh motivate their excellence as trainee teachers. They stated that the Institute of Teacher Education Campus Ipoh have appropriate classrooms, science laboratories, computer lab, playground, gym, extensive resource centre and is full of scholarly materials, speed "Wi-Fi" facility, and place of residence that is the very adequate hostel rooms. With these facilities, the respondents feel motivated to study in this institute.

\subsubsection{Support and Encouragement by Family Members}

The third pattern of motivation is the support and encouragement by family members. A total of 6 respondents have stated that support and encouragement that are provided by their family members motivate their excellence as trainee teachers' in this Teacher Training Institute. Family members include their parents' and respondents that have been raised by relatives claimed that aunt and uncle are the main source that motivates them to continue their studies. Conversely, two respondents stated that their family members who are indulging in the teaching profession are also the source that motivates them.

\subsubsection{Teachers in the Primary School}

Teachers who have taught the respondents' in the primary school are another motivational factor. A total of 6 respondents, have stated that the attitude of their primary school teachers have motivated them to be successful in this Teacher Training Institute. Their dedication, responsibility, patience, concern about the success of the students gave positive reinforcement on respondents to be a useful person. At the same time, the methods used and the services provided by the teachers in primary schools during their schooling time foster interest in the respondents to be a good teacher.

\subsubsection{Classmates}

In this pattern, a total of 4 respondents indicated that their classmates are a source of motivation that motivates them to be successful trainee teachers in the institute. They get motivated by their classmates. According to them, their classmates play an important role in the success of a teacher in motivating themselves. Their classmates who possess different talents and positive attitudes have motivated the respondents' to study. Respondent stated that the attitude of their classmates in helping each other has facilitated the trainee teachers to have high determination and self-confidence in all aspects of learning in a classroom. Respondents' have stated that their classmates own their individual skills, thus, this has made them to compete each other to acquire knowledge in order to obtain high marks. A respondent has stated that the ability of one of their classmates to speak the English language fluently has motivated the others. He/She has also stated that his classmate who can speak the English language fluently does always provide guidance to others who are unable to converse in that language.

On the other hand, classmates who provide guidance and instruction made them more mature in this education field. One respondent stated that the spirit of his colleagues to succeed in a challenging situation, namely the death of a family member to be a motivation factor to continue to become a good teacher.

\subsubsection{Ambition, Dreams and Desire}

Ambitions, dreams, and desires to become a good teacher also affect teacher motivation for excellence. Some 
respondents' ambition is to become teacher when they grow up. Therefore, when they obtained the opportunity to achieve their ambition, this directly encouraged and motivated these respondents' to become an excellent teacher. When the needs are fulfilled according to their desire, thus, the desire will develop to the maximum level and satisfaction can be gained. Hence, the respondent has self motivation to develop their self-achievement. Respondent has stated that the ambition, dreams and desire to become teacher have motivated them to become excellent trainee teachers'.

\subsubsection{Teaching Method}

Teaching methods used by the lecturers in the teaching and learning process have increased the motivation level of the respondents' towards success. According to 5 respondents, teaching and learning methods used by lecturers helped them to achieve the teaching and learning objectives. Especially the group work and presentation activity that are conducted in the classroom have motivated the trainees. This condition has made the respondent to be prepared in providing idea or opinions voluntarily and bravely during the group activity together with the other trainee teachers. This directly made the group and individual presentation activity to improve the self-confidence of respondents' to present a good presentation. According to respondents, although they feel shy, nervous, and lack in confidence at the beginning but as the time goes respondents have trained themselves to be brave and confident to themselves.

\subsubsection{Teachers' Role}

Through reading, researchers found that respondents' view teachers' role as an encouragement towards self-achievement. As future teachers' that will become role model to the children, respondents know their aims and roles. Respondents understand that teachers role serve as guide for their pupils'. They feel without a teacher, an individual will not succeed. This statement motivates the respondents to become an excellent trainee teacher. Respondent has also stated that teachers play the main role in shaping the young generation. Examples set by the teachers and guidance that a teacher provides can shape a student's attitude and behaviour. Teachers form individual with many skills and capabilities. Teachers role have create awareness among the respondents to form individuals who are high in moral values. Two respondents that can appreciate the education concept and objective of teaching profession by motivating themselves.

\subsubsection{Teaching Experience}

Experience gained during attending the teaching practice or practicum also motivates the trainee teachers towards excellence. According to 2 respondents, practicum session provides much experience and changes in oneself to instill moral values so as to shape knowledgeable generation in the future. At the same time, when undergoing practicum, respondent gained many memorable experience and bad experience. The mistakes during practicum have developed the braveness of the respondent to study well in Teacher Training Institute.

\subsubsection{The Love towards Mother Tongue}

In this pattern, there were 2 respondents who feel the love towards mother tongue that is the Tamil language as a source that motivates them towards excellence in Teacher Training Institute. They have stated that the desire to serve for Tamil Language has encouraged them to become a Tamil language teacher in Primary School. Researcher feels that this attitude will motivate the respondents to perform well and achieve success during their days in Teacher Training Institute.

\subsubsection{Self-confidence and Life Goals'}

2 respondents feel self-confidence to achieve goals in life through the teaching profession has motivated them towards excellence. In their point of view, self-confidence can shape them to become a successful trainee teacher in the process of achieving their life goals'.

\subsubsection{Surrounding or Environment}

2 respondents find appropriate surrounding in the studying place can motivate an individual to achieve success. The environment around Teacher Training Institute motivates respondents to become an excellent trainee teacher. At the same time, a peaceful and harmonious surrounding facilitates respondents' to attend classes normally. The surrounding factor too provides in-depth determination for them to continue their studies. A respondent has stated that the location of his /her house, which is near to the institute, has motivated him/her to succeed in their studies. Initially, the seniors have influenced them to become a teacher.

\subsubsection{Systematic, Concern and Friendly Administrations'}

Besides all the other factors, effective management of school and the concern of administrators have been a motivational factor for 2 respondents. The student affairs' department in Teacher Training Institute is always 
ready to help the trainees. Besides, the friendly attitude of the Teacher Training Institute citizens as whole has increase the spirit of the trainees to work towards excellence.

\subsubsection{Curricular Activities and Outdoor Education}

Besides activities in the classroom, all trainee teachers should undergo outdoor education activities such as Co-curricular activities, Work movement (team activities-Gerko), "Teachers" Self Development Scheme (Bina Insan Guru - BIG) and Community Service. Gerko is done during lecture time in the Teacher Training Institute and through $B I G$ the programs conducted off campus, such as camping, swimming, and jungle-trekking. Community Service activities that are carried out on elements of the welfare to the local community. 2 respondents found gerko activities, $B I G$ inspire them to become an excellent teacher. These activities have motivated them to develop the qualities of a teacher trainees', such as the nature of courage, self-reliance, the spirit of trying, dedicated and responsible.

\section{Conclusions}

Essay analysis is divided into two parts. In the first component, the results were analyzed for the related patterns of factors that motivate excellence trainee teachers in the institute. While in the second component, the researchers determine how these factors motivated trainees. There are many factors that motivate excellence trainee teachers in the institute, especially the trainee teachers of the Tamil option. In education, essays are used for many purposes and are written in many ways. Essays written were evaluated to determine the writing skills of students and to what extent the students are able to express the contents related to a topic of discussion. However, in writing, essay also serves as a way to develop ideas in the mind of a student. Essay writing can also help produce excellent writers.

In the process of teaching and learning, encouragement or motivation is the need to attract trainees to attend lectures either on campus or off campus. In order to form highly motivated, lecturers need to use different approaches, methods, techniques and teaching aids to attract trainees to appreciate the lesson. Motivation serves as a driving force in teaching and learning in the classroom. It can act as determinants of teacher excellence. Student teachers are usually motivated by a lecturer is more interested in learning and this helps to accelerate the construction of the concept of achievement, thus helping the achievement of learning objectives. Therefore, lecturers need to know how to attract interest and attention of trainee teachers.

Lecturers can use all the skills and facilities available in the institute to attract trainees. Different approach can help the student trainee teachers developed in terms of academic, curriculum and personality. It can also help build competitive nature of trainee teachers and increase their survival skills to move forward and become a dedicated and excellent teacher in every way.

\section{Recommendations}

\subsection{Lecturer}

Effective teaching sessions results in the delivery of knowledge from lecturer to student teachers to succeed and learning occurs. In fact, the effectiveness of teaching depends on the ability of lecturers to use effective teaching skills to facilitate trainee teachers. Therefore, lecturers need to use a variety of techniques, strategies, methods and approach which are most appropriate to stimulate interest in trainee teachers towards learning.

\subsection{Trainee Teachers}

All trainee teachers must and should be required to take part in all academic and extra-curricular activities to increase their motivation. Trainee teachers need to be motivated so that they undergo the teaching courses successfully.

\subsection{Administrators}

The administrators also must continue to manage in a systematic way as stated by the respondent in their essays. Cooperation between the administrators and teaching staff should be maintained and enhanced.

\subsection{Teachers Education Division, Teacher Training Institute and Ministry of Education}

The Teachers Education Division, Teacher Training Institute and Ministry of Education can use these findings to develop appropriate plans and programs to enhance the motivation and promotes quality among teacher trainees in all Teacher Training Institute in Malaysia.

\section{Proposal for Upcoming Study}

Hermeneutics analysis method can also be used to study other areas that are considered to improve academic performance and curriculum of teacher trainees. The researchers also suggested that this qualitative research 
continues to guide the future. The researchers suggested that in future studies, larger sample involving Trainee teachers of other options such as Malay Studies, Chinese Studies and others can be conducted.

\section{References}

Abdul Rahman Abu Bakar. (1993). Satu kajian terhadap ciri-ciri pengajaran guru yang berkesan melalui Analisis Hermeneutik. Unpublished Master in Education Thesis, Universiti Sains Malaysia.

Berry, B. (1988). Labour market choices and teacher reform: Policy options for the public school of the twenty-first century. Teaching and Teacher Education 4(1), 71-81. http://dx.doi.org/10.1016/0742-051X(88)90026-1

Bontempo, B. T., \& Digman, S. (1985). Entry level profile: student attitudes towards teaching profession. ERIC. ED 258-949.

Brown, M. M. (1992). Caribbean first-year teachers' reasons for choosing teaching as a career. Journal of Education for Teaching 18(2), 185-195. http://dx.doi.org/10.1080/0260747920180207

Cheah et. al. (2004). Sikap Guru Pelatih Terhadap Pengajaran Matematik Dalam Bahasa Inggeris. Jurnal Penyelidikan. MPSAH.

Cheng, Y. C. (1996). Profiles of organizational culture and effective schools. School Effectiveness and School Improvement, 4(2), 85-110. http://dx.doi.org/10.1080/0924345930040201

Chuen, K., L., F., \& Newson, G. (1999). The views of pre-service and novice teachers on mathematics teaching in South Africa related to their educational experience. Educational Research, 41(1), 23-34. http://dx.doi.org/10.1080/0013188990410103

Crow, L. D., \& Crow, A. (1983). Psikologi Pendidikan Untuk Perguruan. Kuala Lumpur: Dewan Bahasa dan Pustaka.

Dilthey, W. (1976). Wilhelm Dilthey: Selected Writings. Cambridge University Press, Cambridge. (Edited and translated by H. P. Rickman.).

Ethington, C. (1988). Women's selection of undergraduate fields of study: Direct and indirect influences. American Educational Research Journal, 25, 157-175. http://dx.doi.org/10.2307/1163078

Evans, H. (1993). The choice teaching as a career. Social and Economics Studies, 42(2\&3), 225-242.

Hull, C. L. (1943). Principles of behavior. New York: Appleton-Century.

Kamalularifin et. al. (2005). Tahap Ketrampilan Emosi Guru-guru Pelatih Opsyen Kemahiran Hidup Kursus Perguruan Lepasan Ijazah dan Kursus Perguruan Diploma Malaysia di Dua Buah maktab Negeri Johor. Fakulti Pendidikan, Universiti Teknologi Malaysia.

Loganathan, (1992). Hermeneutic Analysis of Discourse. International School of Dravidian Linguistics, India.

Loganathan, K. (1996). Metaphisica universalis of meykandar. World Saiva Council of Meykandar Adheenam, London.

Marshal, D. G. (1986). Student teacher motivations for choosing teaching as a career. Teacher Education, 29 , 75-83.

Muhammad, et. al., (2010). Profil Kecerdasan Emosi Guru Pelatih Bahasa Mengikut Tahun Pengajian. GEMA Online Journal of Language Studies, 10(2).

Mulyasa, P. (2005). Menjadi guru profesional: Menciptakan pembelajaran kreatif dan menyenangkan. Bandung: PT Remaja Rosdakarya.

Palmer, R. E. (2003). Hermeneutika, Teori Baru Mengenai Interpretasi, terj. Musnur Hery. Yogyakarta: Pustaka Pelajar.

Strauss, \& Corbin. (1998). Basics of Qualitative Research Techniques and Procedures for Developing Grounded Theory (2nd ed.). Anselm Strauss and Juliet Corbin Sage Publications: London 1998.

Suppiah, N. (2003). Proses Kognitif Dalam Penulisan Esei Melalui Analisis Hermeneutik. Unpublished Doctored Thesis, Universiti Sains Malaysia.

Thomas, K. R. (1984). Occupational status and prestige. Vocational Guidance Quarterly 33, 70-75. Yee, S.M.L. 1990. Careers in the classroom: When teaching is more than a job. Columbia: Teachers College Press.

Yong, B. C. S. (1994). Factors determine the attractiveness of the teaching profession. Brunei Darusalam as perceived by teacher trainees. Journal of Education for Teaching, 20(1), 113-125. http://dx.doi.org/10.1080/0260747940200112 